\title{
Impact of Rainfall Harvesting as a Fertigation Resources Using Autopot on Quality of Melon (Cucumis melo L.)
}

\author{
Nurpilihan Bafdal ${ }^{1, *}$, Sophia Dwiratna ${ }^{1}$, Siti Sarah $^{2}$ \\ ${ }^{1}$ Departement Agriculture Engineering and Biosystem of Agriculture Industrial Technology Faculty, \\ Universitas Padjadjaran, Bandung, West Java, Indonesia \\ ${ }^{2}$ Fresh Graduate Student of Agriculture Industrial Technology Faculty, \\ Universitas Padjadjaran, Bandung, West Java, Indonesia \\ *Corresponding author. Email: nurpilihanbafdal@yahoo.com
}

\begin{abstract}
Global climate changes which cause increasing the dry season and impact of decreasing in water resources. Water has an important role in agriculture sector especialy to the process of plant growth and water use efficiency while rainfall harvesting will impact of water quality .Fertigation and using autopot is an alternative of water used efficiency and plant nutrition. Fertigation also will affect the ability of melon (Cucumis melo L) to produce quality of melon especially water use efficiency, carbohydrate, protein, mineral, vitamin $\mathrm{C}$ and sweetness.. The methode of the research is descriptive analysis. The results showed that rainfall harvesting quality contained $\mathrm{pH} 5,6$; electronic conductivity (EC) $0,22 \mathrm{mS} / \mathrm{cm}$; TDS 3,075 mg/l; TSS 7,0 mg/l; and turbidity 5,29 NTU ;all thing appropriate to the melon needs except EC. Fertigation was significant effect to the yield of melon and avarage value of water used efficiency was $93,89 \%$ and total sweteness $10 \%$ brix; carbohydrate $2,65 \%$; proten $1,94 \%$; fat $0,3 \%$; ash $0,89 \%$ and vitamine $\mathrm{C} 26,18 \%$. In conclusion impact of water rainfall harvesting suitable and could applied for fertigation resources and using auto pot.
\end{abstract}

Keywords: fertigation, autopot, rainfall harvesting, global climate change

\section{INTRODUCTION}

Generally due to climate change will impact of seriously adverse for irrigation and agriculture; which during the dry season water from rainfall decrease by $20-25$ percent and in the wet seoason water from rainfall decrease by $10-15$ percent [1]. In the dry seasons demand of water for agriculture sector as a irrigation increased.

Due to global climate change; water crisis especially in the dry season in many parts of the agriculture area applied of irrigation sector use water efficienctly. Water use efficiency in agriculture is strongly influenced by main system water management. [2] the scope for existing improved control over water distribution is determined by (1) the availability skill and motivation of operating personal and (2) The physical infrastructure certain combination control structures are inherent more suitabler than other; (3) the clarity perecion and flexibility, or otherwise of the operating rules;

Figure 1 below show that increasing of length of dry season due to climate change.The length of dry season on 1991- 2003 start from second week of May to second week of October. But due to climate global change the length of dry season (2004- 2011) increased from third week of April to fourth week of October. In conclusion the length of dry season incresed two month during of ten years. The data collect at station climatology at Universitas Padjadjaran' at campus Jatinangor of West Java Indonesia.

Appropriate technology such as water resources of irrigation should be require. Irrigatted agriculture is essential to growth plant and to pruduce yielding more food. Rainfall harvesting can provide which have been predicted to occur more frequently as the climate change and improved irrigation method and innovation harvesting of rainfall; is an alternative solution to irrigation resources to increases crop production.

The delivery of dissolved fertilizer to the roots of crops in the field using irrigation water is known as fertigation Fertigation which is a mixed of fertilizer and irrigation and applied to the crops. Fertigation for melon plant are basic requirement to increased high yield.

Surface irrigation method were historically used to provide water for crop evapotranspiration (ET) requirement [4][6].

Melon needs temperature between $25-35{ }^{0} \mathrm{C}$. Figure 2 showed that temperature in the green house during whole growth of melon. 
Figure 2 showed that minimum temperature during 10 hours start from $7 \mathrm{am}-5 \mathrm{pm} .18,1{ }^{0} \mathrm{C}$ and maximum temperature at noon $31,17{ }^{\circ} \mathrm{C}$ and after noon at $5 \mathrm{pm}$
$26,14{ }^{0} \mathrm{C}$. Maximum temperature at noon were solved the problem which is applied water fogging in the green house.

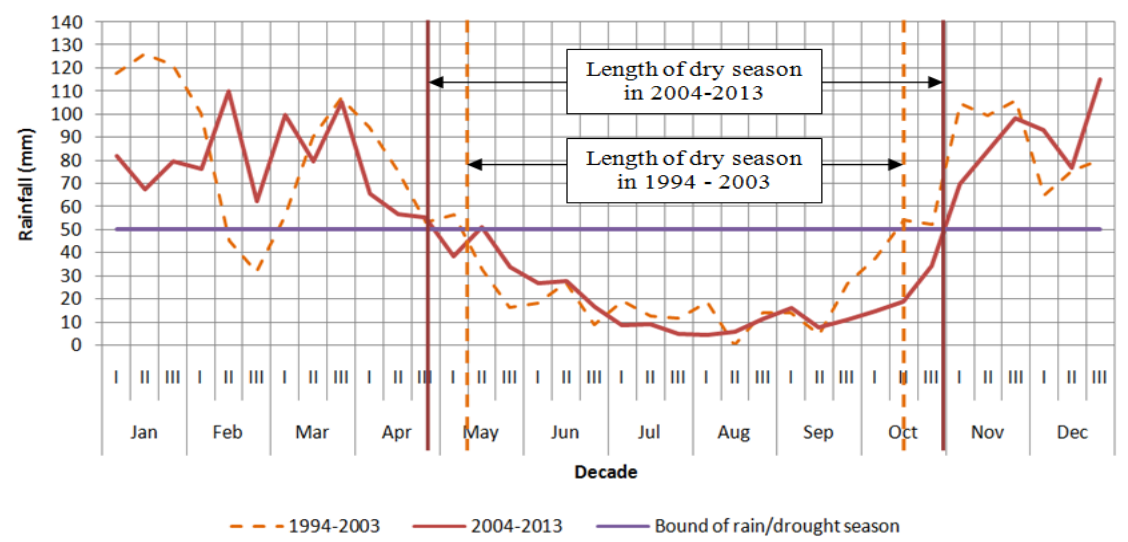

Figure 1. Rainfall Grafic Decade from 1994 - 2003 and 2004 - 2013 at Jatinangor Climatology Station

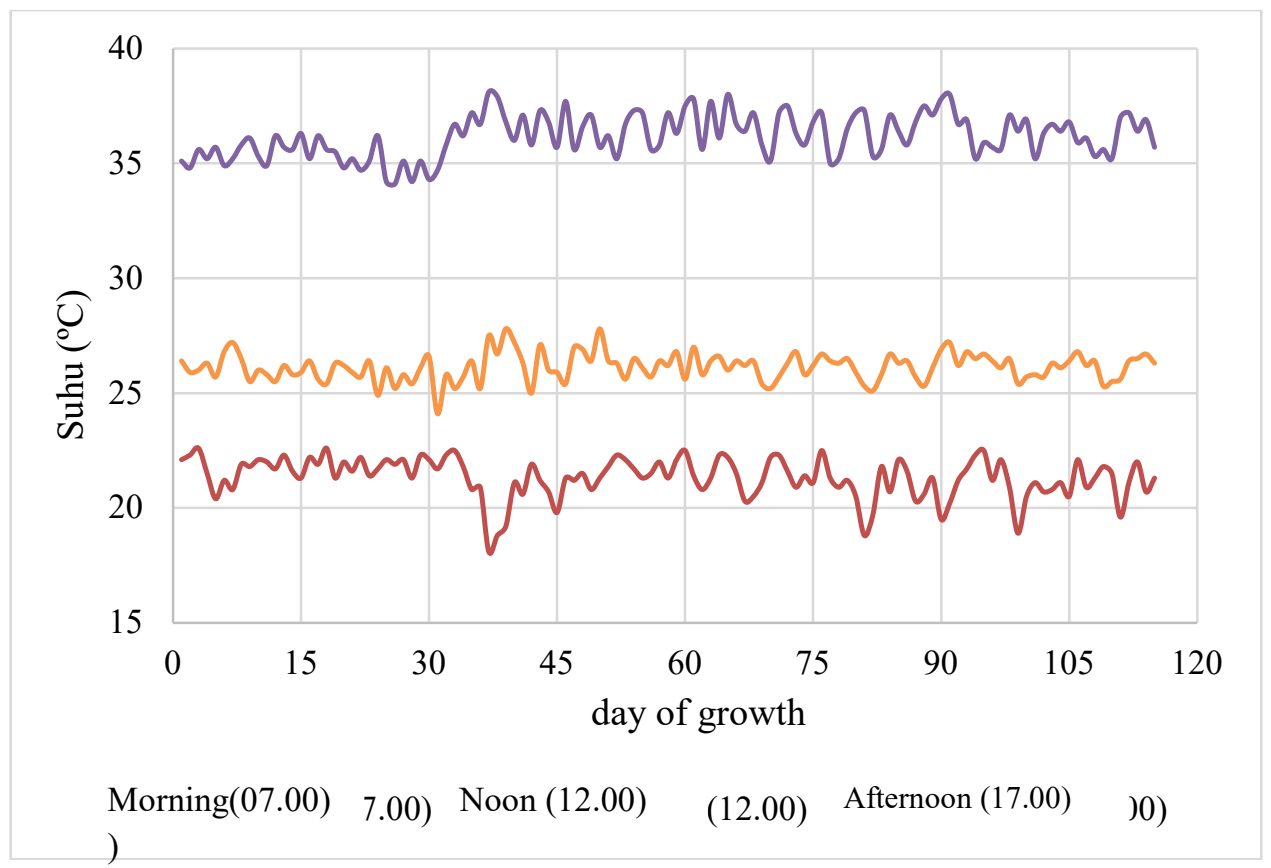

Figure 2. Grafic change Temperature in Green House of Whole Melon Growth.

\section{METHOD}

\section{A. Problem of Rainfall Harvesting as a Fertigation Resources.}

Irrigated agriculture seeks more water to grow more food. However , demand for industrial domestic and environmental uses supply is also increasing rapidly; water is used inefficiently in agriculture. There are large losses in conveyance up to $50 \%$ in small field channels and in application up to $60 \%$. Climate charge is predicted to increase temperature, reduce regions already experiencing water stress. 'Water from rainfall harvesting from roof top of green house and suppliees for agriculture are some time have a increasing polluted. Water from rainfall containing naturally occurring electronic conductivity (EC) very low around $0.022 \mathrm{mS} / \mathrm{cm}$ and $\mathrm{pH}$ also low around 5 and not appropriate for melon needs.

Distribution water between farmers on fertigation scheme is generally inequitable, even where water rationing operation. In arid areas effects on soil structure of irrigating with low quality. In many countries the constraints of development of rainfall harvesting especially in humid tropic is they have only two seasons these are dry 
season and wet seasons. Water rainfall harvesting have been harvest during the wet season. Where water is collected in the torents and may be used for fertigation in dry season.

The present demand for irrigation water can potentially be reduced if the effectiveness of rainfed agriculture can be improved. There are now have apropriate of technology which is rainfall harvesting; improved irrigation resources and also crop varieties for dry areas and still needed. The other problem is how irrigated agriculture is to reduce its high share of the overall water resource. One of alternative is improving water use efficiency at the field level; introducing demand management ; developing crops with lesser water demand [3]

\section{B. Fertigation and Autopot}

\section{Fertigation}

The use of fertigation is gaining popularity because of it's efficiencies in nutrient management, time and labour and potentially a greater control over crops performance. This is a technology which widely practicein the production of high value annual vegetable crops under protective structures and is sometime reffered to as nutrient film technique or NFT.In soilless solution culture all the plant's mineral nutrient requirement must be supply in the irrigation water.

Fertigation represent as a natural extension of the hydroponics concept, and is now widely practiced in horticultural industries particularly permanent planting of crops such as citrus, olives and almonds. Fertigation is most successful when combination with drip irrigation [3] The advantages of supplying mineral nutrients to crops roots using fertigation include: (i). reduced delivery cost of fertilizer and low labor requirement.।; (ii). greater control of nutrients are delivered to greater fertilizer; (iii) more control application of specific nutrient during stage of crop development and (iv). potencial to reduced fertilizer losses. Disadvantage of fertigation which are: (i) high initial cost; (ii) higher operating costs and (iii). chemical reactions between some types of fertilizer when mixed potentially causing significant equipment blockages.

\section{Autoppot System}

Autopot system is a pot an efficient and environmentally friendly tehnology that revolves around the SmartValve, which feeds plant on demand. The eco friendly autopot system allow for sustainable and consistent crop cultivation which is independent of soil. Fed with nutrient rich water, crops are protected from soil borne diseases and are kept healthy without the use of harmfull chemical. Advantage of used of autopot are: (1). resource efficiency. There is no water wastage or nutrient run-off as plants feed on demand; (2) environmentally friendly; without nutrient run-off there is no pollution to surrounding water systems; (3). flexibility; the system allow for agriculture to thrive in areas that would normally be seen as non conductive to farming such as non productive or marginal land, or even rooftop; (4) automated and simple, because this system is fully automated, farming on a commercial scale becomes easier and less laboriou and (5) cop yield quantity and quality are consistent. Figure 2 below show that autopot with SmartValve [5].

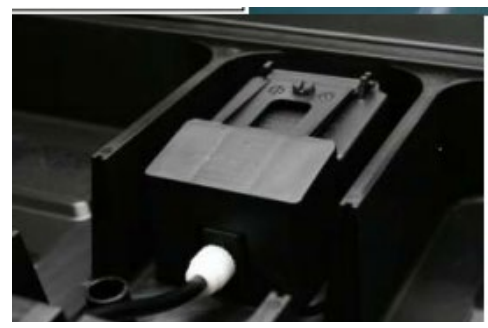

Figure 3. Smart valve in side autopot (Source: Nurpilihan et al., 2016)

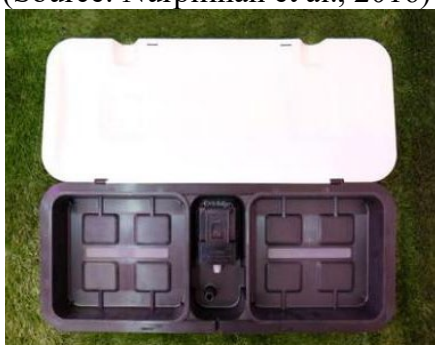

Figure 4. Autopot

(Source: Nurpilihan et al., 2016)

\section{RESULTS AND DISCUSSION}

\subsection{Water Rainfall Harvesting Quality}

Water quality problem affecting of water use in agriculture and should be included in one or other catagory. Water rainfall harvesting from the roof top supllies are being increasingly polluted by agricultural; domestic urban and industrial use. Quality of water rainfall harvesting depend on the system of harvested in catchment area.The reseach use of water rainfall harvesting from the roof of the green house. Table 2 below show quality of rainfall harvesting.

Table 1. Quality of Water Rainfall Harvesting

\begin{tabular}{|l|l|l|l|}
\hline No & Parameter & \multicolumn{1}{|c|}{ Unit } & \multicolumn{1}{|c|}{$\begin{array}{c}\text { Analysis } \\
\text { Sample }\end{array}$} \\
\hline 1 & EC & $\mathrm{mS} / \mathrm{cm}$ & 0,22 \\
\hline 2 & PH & - & 5,56 \\
\hline 3 & TDS & $\mathrm{mg} / \mathrm{L}$ & 3,075 \\
\hline 4 & TSS & $\mathrm{mg} / \mathrm{L}$ & 7,0 \\
\hline 5 & Turbidity & NTU & 5,29 \\
\hline
\end{tabular}

Water rainfall harvesting from Table 1 showed that apprecite and suitable for irrigation resources for crops (FAO., 1985). But for melon the quality of fertigation should be increasing especially electronic conductivity (EC) which are melon needs EC $0,25 \mathrm{mS} / \mathrm{cm}$ for initial stage; 1,0 for mid season stage and 2,0 for late season. Melon also needs pH 6 to 7; Total dissolved solids (TDS) $11 \mathrm{mg} / \mathrm{l}$; total suspended solids (TSS) 5 to $6 \mathrm{mg} / \mathrm{l}$ and turbidity 5-6 NTU. Quality of water rainfall harvesting 
(Table 2) not significant impact on melon quality except EC. To solved this problem solution of the nutrient should be more add such as nirate; fosfate and kalium

\subsection{Quality of Melon (Cucumis melo L)}

The results of quality on melon yield were assested on water content; corbohydrate ;protein; ash; vitamin $\mathrm{C}$ and sweetnees. Table 2 show the quality of melon

Table 2. Quality of Melon by Using Fertigation From Water Rainfall Harvesting

\begin{tabular}{|l|l|l|}
\hline \multicolumn{1}{|c|}{ Parameter } & \multicolumn{1}{|c|}{ Unit } & $\begin{array}{c}\text { Quality analysis of } \\
\text { melon }\end{array}$ \\
\hline Water & $\%$ & 94,265 \\
\hline Fat & $\%$ & 0,3 \\
\hline Ash & $\%$ & 0,89 \\
\hline Protein & $\%$ & 1,948 \\
\hline Carbohydrate & $\%$ & 2,65 \\
\hline Vitamin C & mg/100grm & 26,18 \\
\hline Sweetness & $\%$ brix & 10 \\
\hline
\end{tabular}

In general Table 2 showed that quality content of melon by using fertigation from water rainfall harvesting was good. Tjahyadi (1987) noted that good melon fruit content of ash $0,3-0,4 \%$; protein $0,6 \%$; carbohydrate $4-6 \%$; vitamin C $25 \%$.and sweetnees $10 \%$ brix.

\subsection{Total Water Use of Melon Using Auto Pot}

Applied of water use as a fertigation using auto pot show on Table 3 below

Table 3. Total Water use of Melon Using Auto Pot (litre)

\begin{tabular}{|c|c|c|c|}
\hline $\begin{array}{c}\text { Water } \\
\text { Use }\end{array}$ & $\begin{array}{c}\text { Number } \\
\text { of Plant }\end{array}$ & $\begin{array}{c}\text { Water Use } \\
\text { whole life of } \\
\text { Plant }\end{array}$ & $\begin{array}{c}\text { Water Use } \\
\text { Plant/day }\end{array}$ \\
\hline 817,78 & 144 & 54,29 & 0,61 \\
\hline
\end{tabular}

Table 3 showed that water requirement for melon very efficient only 0,6 litre/crop/day. Comparing with 1,3 litre/crop/day/ (FAO 1987). The efficiently due to all plants growth in the auto pot and there is no water wastage or nutrients run off as plants feed on demand.

\section{CONCLUSION}

1. Impact of water rainfall harvesting from the green house of roof top not signficant effected with quality of melon and suitable for fertigaton.

2. Quality content of melon were ash $0,89 \%$; protein o, $1,94 \%$; carbohydrate $2,65 \%$; and vitamin C $26,8 \%$; fat $0,3 \%$ and sweetnees $10 \%$ brix.

3. Total water requirement fertigation by using auto pot were 54,19 litre/plant whole life of melon and 0,61 litre/plant/day.

4. Water rainfall harvesting could applied and suitable for fertigation by using auto pot.

\section{ACKNOWLEDGMENT}

The authors would like to thank the Rector of Universitas Padjajaran for the Academic Leadership Grant's funding, trough internal grant number 431/UN6.431/PL/2018.

\section{REFERENCES}

[1] Ragab. 1999. Problems affecting water use for agriculture. Riview of Research and development needs in irrigation and drainage.

[2] Janusz And Southamton. "Riview Of Research And Development Needs In Irrigation And Drainage. 2001.

[3] Michael Treeby. 2011. Fertigation: Delivering Fertigation in the irrigation water. Reserch Horticulturist, Industry and Investment, Dareton Primy Industries Institute, Dareton, NSW.

[4] Nurpilihan. 2018. Water Harvesting as a Techonological Innovation and Greater Solving of Climatic Change Impact to Supply Fertigation. International Journal on Advanced Science Engineering Information Technology. Vol.8(2018) No. 6 ISSN: 2088-5334

[5] Nurpilihan, 2016. "Rainfall Harvesting as Resources of Self Watering Fertigation System with Various Growing Medias, Int.J. Adv.Sci. Eng.Inf. Technol., vol.6 no. 5, pp. 787-792,

[6] A. Franco, P.J. Perez-Saura, J.A. Ferna Ndez, M.Parra and A.L. Garcia. 2015. Effect of two irrigation rates on yield, incidence of blossomend rot, mineral content and free amino acid levels in tomato cultivated under drip irrigation using saline water. The Journal of Horticultural Science and Biotechnology. Vol. 74. $1999-$ Issue 4

[7] Tjahjadi, N. 1987. Bertnam Melon, Yogjakarta; Kanisus. 